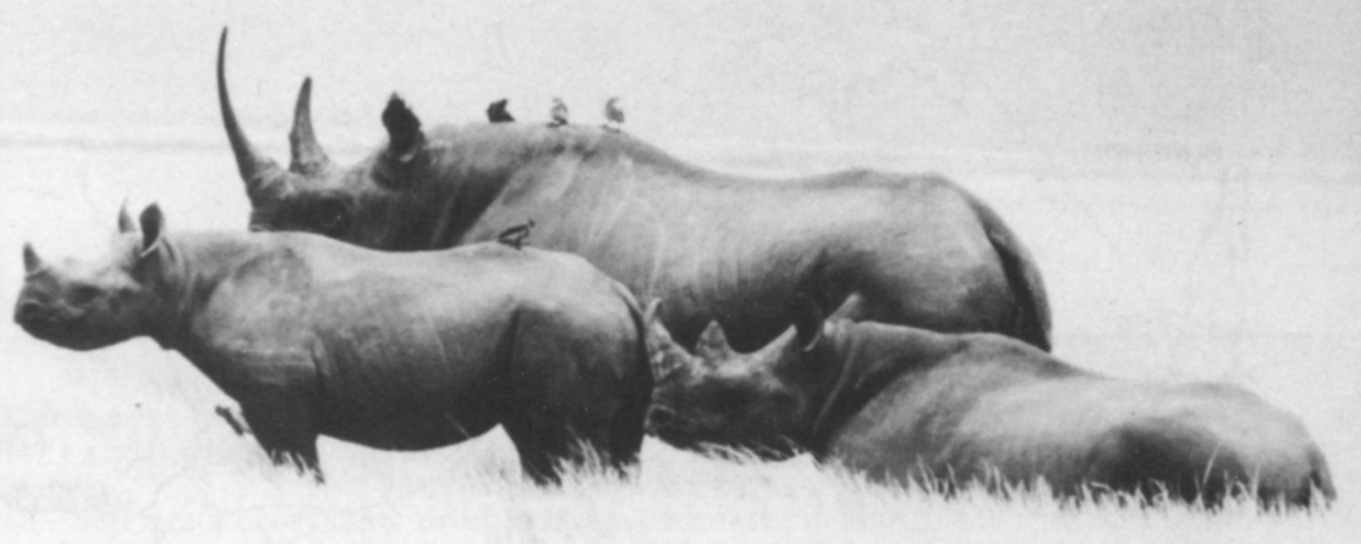

\title{
Black Rhino Disaster in Tanzania
}

\section{Markus Borner}

The black rhino will be exterminated soon in northern Tanzania if poaching is not stopped, says the author, after surveying eight national parks and game reserves, either from the air or on the ground, or both. Tanzania is making great efforts to stop the poaching, but essential equipment is desperately short, and much more outside help is needed.

The black Rhinoceros Diceros bicornis is still the most numerous of the five rhino species. But in the last few years it has been the one most heavily poached, and most East African populations have been drastically reduced. Kenya in the last ten years has lost over 90 per cent of its black rhinos, and today fewer than 1500 survive in scattered populations. ${ }^{13}$

In a recent report to the IUCN/SSC African Rhino Group Dr Esmond Bradley Martin attributed the present onslaught to an increased demand for rhino horn on the world market, ${ }^{4}$ not only for the traditional medical purposes in the Far East, but also for the new market in North Yemen, where the horns are carved into dagger handles, and where 22,645 kilos of rhino horn were imported between 1969 and $1977 .{ }^{4}$ The world market has consumed at least 7.75 tonnes of rhino horn annually in recent years, for which about 2580 rhinos were killed every year. Because of the growing demand the price in the last four years has increased some 2000 per cent, reaching a minimum wholesale price of US $\$ 675$ a kilo in South-east Asia in 1979 . Such prices naturally encourage poaching. Poachers became well organised, well equipped and ruthless. In the national parks of northern Tanzania rhino poaching only became serious after 1975, but it has now caused a most dramatic decline in numbers in all affected areas.

The surveys discussed in this paper were carried out on behalf of the Tanzanian Rhino Task Force and the Frankfurt Zoological Society to establish the black rhino's status in northern Tanzania. The areas surveyed were: 


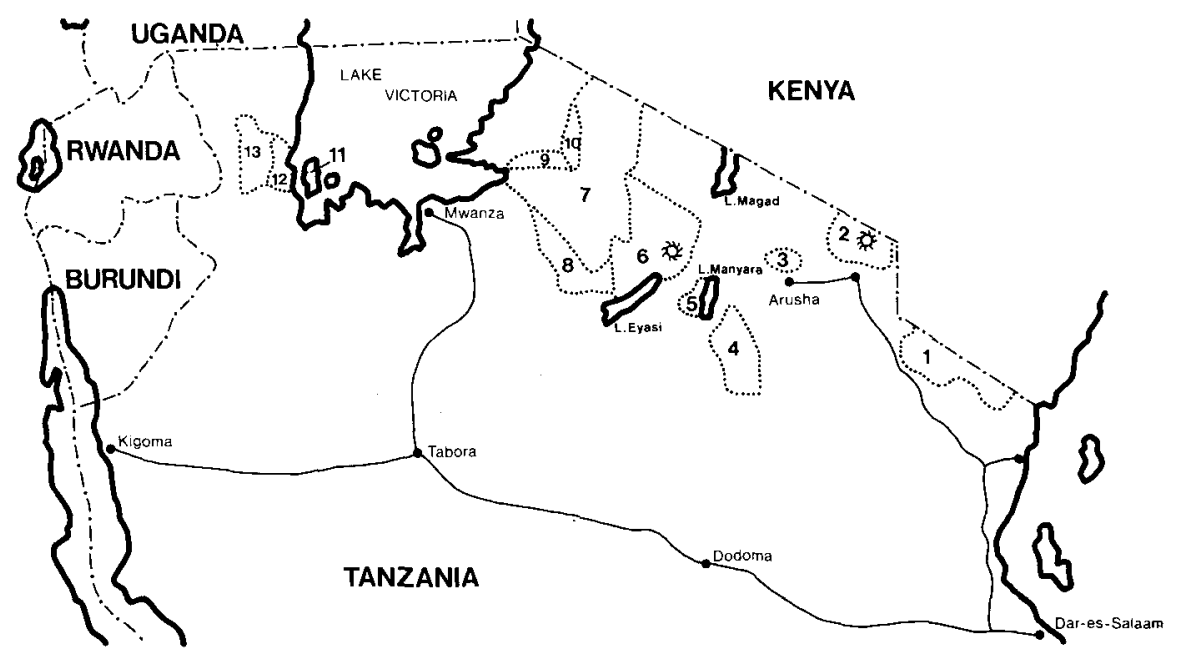

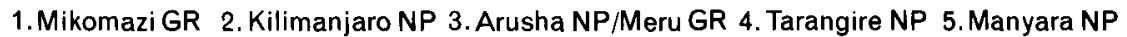
6. Ngorongoro Conservation Unit 7.Serengeti NP 8. Maswa GR 9. Grumeti Controlled Area 10. Ikorongo Controlled Area 11. Rubondo NP 12.Biharamulo GR 13. Burigi GR

Serengeti National Park including the adjacent Maswa Game Reserve

Grumeti and Ikorongo Controlled Areas

Ngorongoro Conservation Unit

Tarangire National Park

Lake Manyara National Park

Arusha National Park and Mount Meru Game Reserve

Rubondo National Park

Burigi and Biharamulo Game Reserves.

\section{Methods}

All aerial counts were made in a Cessna- 182 belonging to the Frankfurt Zoological Society with a front-seat observer/navigator and two rear-seat observers in addition to the pilot.

Aerial block sampling as described by $\mathrm{M}$. Norton-Griffiths ${ }^{25}$ was used in Serengeti and Tarangire.

Aerial total counts were made in the Ngorongoro Crater, the Ndutu/Olduvai area, Moru Kopjes, Serengeti and three selected valleys in the Burigi Game Reserve.

Random transect flights were carried out in Serengeti, Tarangire, Manyara and the Burigi/Biharamulo area. In addition, in Serengeti anti-poaching flights were combined with rhino counts.

Ground counts were carried out from Landrovers, Unimogs and on foot. In the Ngorongoro Crater a total ground count was made, dividing the crater floor into six blocks and searching all blocks simultaneously. For a minimum population estimate a ground survey was carred out in the Burigi area, searching for and measuring rhino tracks. ${ }^{23}$ Road counts were attempted in Tarangire but proved unsuitable. In all areas information of rhino sightings, rhino evidence and poaching activities were collected by park wardens, rangers and scientists.

\section{Serengeti National Park}

Recent estimates of the Serengeti rhino population vary widely. McNaughton, after repeated road counts, estimated 60 to 108 in the combined areas of the Serengeti National Park and the Masai Mara Game Reserve. ${ }^{7}$ The Serengeti Ecological Monitoring Program's (SEMP) aerial survey of the woodlands of 


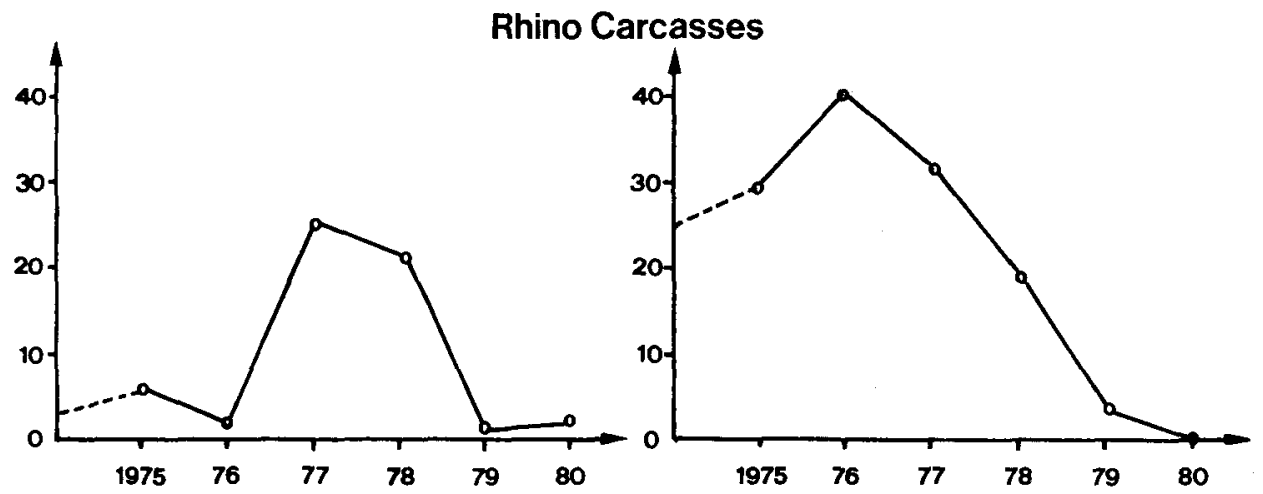

Carcasses of poached rhinos found in the Serengeti National Park (Fig. 1, left) and Tarangire National Park (Fig. 2, right)

the Serengeti ecosystem produced an estimate of about 420 rhinos in the national park. ${ }^{11}$ Mainly based on individual recognition of rhinos in the grass plains, Frame estimated about 700 rhinos in the Park. ${ }^{7}$ His data, however, go back to 1974, before the poaching started to increase, and he ignores the situation in the north and west of the park, where poaching pressure was heaviest. His estimate must, therefore, be considered too high. The SEMP found three main rhino populations in the Serengeti: one in the north around the Mara river, one in the western corridor, and a third around the Olduvai Gorge. ${ }^{25}$ Our own recent survey shows that all three populations have been almost completely wiped out.

In more than 130 hours of low-level anti-poaching flights over the whole park in 1979/80 I saw only two rhinos near Ngare Nanyuki and several near Moru Kopjes. During the aerial block sampling in March 1980, which covered 13.8 per cent of the park, only one rhino was seen south of Ngare Nanyuki. In a total aerial count of the Moru area (392 sq km) nine rhinos, two of them calves, were sighted during the census. An additional survey flight revealed another seven rhinos, one a calf, east of the previously surveyed block. Ground reports from rangers and scientists from the Serengeti Wildlife Research Institute indicate that some individuals survive in the Bologonja/Klein's Camp area two were seen by Norton-Griffiths in 1980 - and some near the Handajega ranger post in the south-west.

The poaching activities in the park are to some extent reflected in the number of rhino carcasses found by the rangers, ${ }^{1}$ shown in figure 1 . But the vastness of the area and difficulties of access, especially in the northern extension, mean that many carcasses are never found. Figure 1 shows a clear peak in the number of carcasses found during 1977/78. But control over the area and the numbers of arrests have varied little from year to year recently, so the drop after 1978 unfortunately reflects not less poaching but the drastic decline in the population.

Black rhinos are by nature solitary and have a low population density. They communicate with one another and orientate within the home range largely by scent marks. ${ }^{9}{ }^{28}$ In a drastically reduced population the marking system cannot be maintained, so that intra-specific communication is greatly reduced and with it the chance of reproduction. It is therefore unlikely that the few scattered individuals surviving in the north and west of the Park are still reproducing.

It must be concluded that the population around the Moru Kopjes, in the 


\section{Former and Present Distribution of Rhino Populations in the Serengeti National Park}

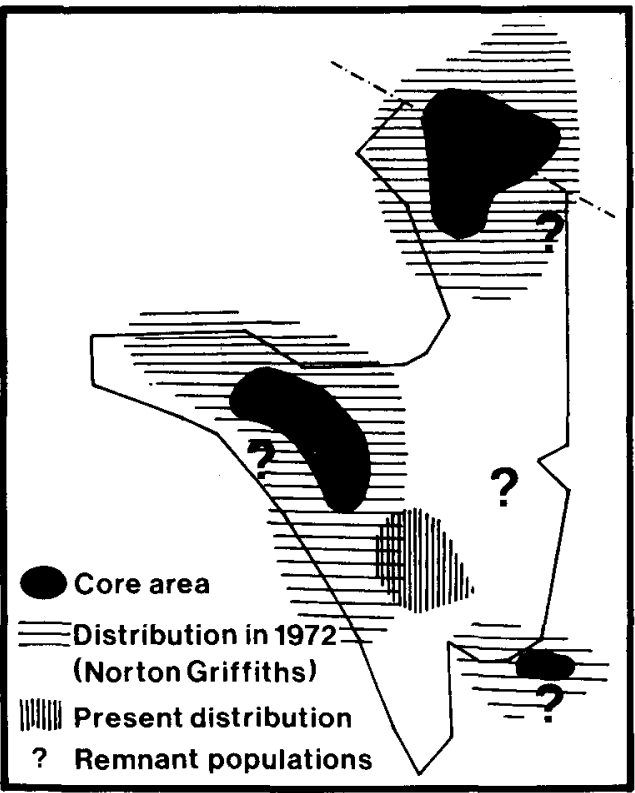

southern Serengeti, is the only viable one in the national park, and the total aerial count of this area (uncorrected) is $\mathbf{1 6}$ observed animals. Applying a correction factor of 1.7 gives an estimate of 25-30 animals. (This is the correction factor used for this kind of habitat - grass plains and open woodlands - in the Ngorongoro Crater survey, where total aerial and ground counts were carried out at the same time). The Moru area seems to be suitable for rhinos throughout the year. Two of their main food plants, Indigofera basiflora and Trifolium masaiense, are abundant there. Goddard found that in the Crater in the wet season 52 per cent of their total food intake was Indigofera; in the dry season 54 per cent was Trifolium. ${ }^{10}$

A reasonable estimate for the whole Serengeti National Park, including the one viable population, is between 50 and 100 .

As a result of this census the Director of National Parks and the Chief Park Warden of Serengeti have intensified anti-poaching activities, and set up a new ranger post.

In the Ikorongo Controlled Area, north-west of Serengeti, there is no evidence of any rhinos. A few may survive in the Grumeti Controlled Area but neither the rangers nor I saw any.

In October 1978 and October 1979 S. Makacha, staff scientist in the Ngorongoro Conservation Area, in a thorough ground survey of the Maswa Game Reserve, found 41 carcasses in the eastern half of the reserve, but saw no live ones. In several recce flights over the area I have seen no rhinos, but a few might survive near the park boundary, and some from the Moru population might wander into the Maswa in the dry season. Human settlements are encroaching on the Maswa Reserve, where there is virtually no control due to lack of equipment. ${ }^{19}$

\section{Ngorongoro Conservation Area}

Up to 1965 Fosbrooke estimated that only about three rhinos were poached annually in the Ngorongoro Conservation Area (NCA), all speared by Masai. ${ }^{6}$ In 1978 the estimate was over 25, mostly killed with rifles by non-Masai poachers. ${ }^{22,}{ }^{27}$ 


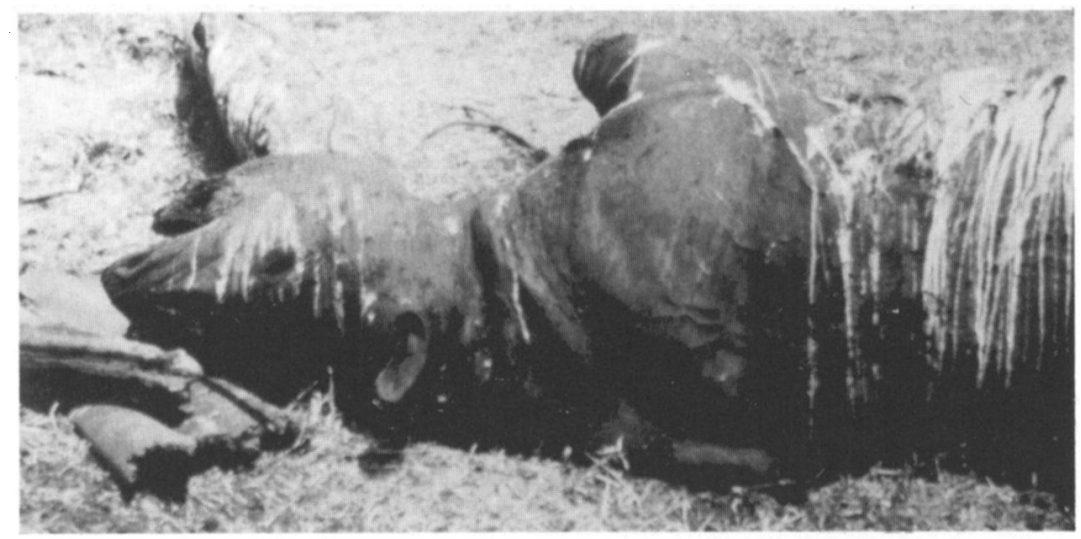

Only the horn removed

In 1966 Goddard counted 108 rhinos on the Crater floor; ${ }^{9}$ in May $1980 \mathrm{I}$ counted 18 in a total aerial survey of the Crater floor, and a total ground count at the same time by the NCA produced 30: hence a correction factor of 1.7 for total aerial counts in this kind of open habitat. (Goddard found that under optimal conditions in the Olduvai area only 50 per cent of the rhinos were seen from the air) ${ }^{8}$ It can be concluded that the Crater floor still harbours about 30 rhinos of which 24 are resident. ${ }^{20}$ The heavy poaching in $1977 / 78$ is reflected in the proportion of adult to young animals: of the 61 individuals Klingel identified in the Crater between 1963-65, 82 per cent were adults; ${ }^{15}$ of the 27 Makacha identified in August 1978 only 26 per cent were adults.$^{18}$ Obviously poachers would go first for fully grown animals with large horns. Since early 1980 the Authority's regular day-and-night patrols in the Crater have reduced poaching there considerably, although it has not been stopped completely.

Three more rhinos have been poached since the count. Ndutu/Olduvai was the third main rhino population of the Serengeti ecosystem. ${ }^{15}$ In the Olduvai Gorge Goddard counted 69 resident rhinos; ${ }^{8}$ in a total aerial count of the Olduvai/Ndutu area in May 1980 we did not see a single rhino. Dr Mary Leakey, who lives and works in the Olduvai Gorge, is certain that no rhinos survive there. ${ }^{16}$ SWRI scientists working in the Ndutu area occasionally see one, probably coming over from the Moru area. In October 1979 a survey south of Ndutu and in the Endulen area found seven live rhinos and four carcasses. ${ }^{18}$

No estimate of numbers in the Ngorongoro highland forests is available. A census based on track measurements will be carried out in the 1981 rainy season. ${ }^{2}$

\section{Tarangire National Park}

Until a few years ago Tarangire was famous for its large rhino population. In 1974 a Mweka Wildlife College rhino census in the Park, using ground transects, gave an estimate of 250 . Heavy poaching seems to have started here earlier than in the Serengeti, with a peak between 1975 and 1977, as reflected by the carcasses found by the park authorities. ${ }^{17}, 21$

An aerial sample count in January 1977 by IUCN/ESCP produced an estimate of $55 \pm 41$ rhinos; $;^{12}$ in August 1979, in an aerial block sampling, covering about 30 per cent of the park, we saw only three. Today the Tarangire rhino population must be less than 20. The Park is difficult to patrol and is desperately short of equipment, and the Tarangire rhinos are certainly threatened with extinction. 


\section{Lake Manyara National Park}

In 1975 a total ground count in the Lake Manyara National Park resulted in an estimate of 35-40 black rhinos. ${ }^{24}$ Between July 1975 and October 1978, 26 rhino carcasses were found ${ }^{14},{ }^{17}$ The Park is small, so probably most of the carcasses were found. The Park authorities put the present population at under ten.

\section{Arusha National Park and Mount Meru Game Reserve}

Mount Meru and its surroundings being densely forested, it is difficult to census rhinos there, but rangers' reports show that both the Arusha National Park and the Mt Meru Game Reserve have lost nearly all their rhinos. Between March 1975 and October 197716 rhino carcasses were found. ${ }^{17}$ The nearly total lack of direct observations, plus the extreme scarcity of tracks, scratching marks and faeces, indicate that only a very few individuals survive today ${ }^{23}$ It is doubtful whether this population is still viable.

\section{Rubondo National Park}

Sixteen black rhinos were translocated to Rubondo Island between 1963 and 1965 , since when five carcasses, two of them calves, have been found. The low visibility in the forested areas makes rhinos difficult to see, but communal dung heaps, scratching marks and footprints are abundant in several parts of the island where the rhinos have also established a network of trails. Direct observation and measurements of tracks show that the population is breeding. Numbers are estimated at about 30 animals. Being an island, Rubondo is easier to protect than other national parks, and the dense forest cover is an additional protection.

\section{Burigi and Biharamulo Game Reserves}

These reserves west of Lake Victoria, together with the surrounding forest reserves, cover nearly $5000 \mathrm{sq} \mathrm{km}$. An aerial survey was made in February 1980 and a ground survey in August. An aerial total count was carried out in the Kasongenye and Ruiza valleys and another unnamed valley, and random transect flights covered 4.1 per cent of the area in the rest of the Burigi-Biharamulo Game Reserves. During the ground survey we searched for rhino tracks mainly around water holes; this survey covered only a very small part of the whole reserve.

Three rhinos were spotted on the aerial survey; one was seen in the ground survey, as well as the tracks, scratching marks and faeces of ten individuals, one a calf. Some rhinos also survive in the surroundings of the game reserves in the north-west and south. So a 'guesstimate' of about 50 to 100 rhinos surviving in the Burigi Game Reserve and its surroundings seems reasonable. A more detailed survey using Standard Reconnaissance Flight Methods is planned for early 1981 .

There is no doubt that rhinos are poached in the area; the skulls of two poached rhinos were found during the ground survey. In March 1980 the Regional Development Committee agreed that the Burigi Game Reserve and its surroundings should be made a national park in the near future. As the area is now completely undeveloped, this will require a great effort by the Game Department, the National Parks Department, the local authorities and outside organisations before the rhinos of Burigi are properly protected. 
I have no first-hand information on the Mkomazi Game Reserve, bordering Kenya's Tsavo National Park, which is soon to be upgraded to a national park. According to the Game Department, very few rhinos may survive there, and it is doubtful if they still form a viable population.

\section{Conclusions}

Tanzania has set aside large areas for its wildlife; national parks and game reserves cover 26.4 per cent of the whole country, so it is not human encroachment that is threatening the rhinos' survival. Although some habitat changes are taking place in protected areas, like the reduction of woodlands in the Serengeti, these are not a factor in the present rhino population decrease. It is poaching that has brought Tanzania's rhinos close to extinction. Few poachers carry sophisticated equipment, but those who do are very difficult to apprehend. Of the 308 arrested in Tanzanian national parks between October 1979 and February 1980, only one carried a .404 rifle and 15 rounds of ammunition..$^{29}$ Only a few groups of rhino poachers are operating in northern Tanzania, but they have been able to wipe out most of the rhinos within a few years.

The Tanzanian Government and the National Parks authorities are doing their best to curb the poaching, but the ranger forces desperately lack equipment - vehicles, graders and radio communication systems which have to be bought with foreign currency. In the last few years only the Frankfurt Zoological Society and the African Wildlife Leadership Foundation have had long-term commitments to help Tanzania National Parks protect their wildlife. Recently IUCN/WWF have contributed a considerable amount of equipment, which it is hoped will lead to a long-term involvement. However, increased anti-poaching activities coupled with the creation of three or four new national parks, calls for more outside help. The rangers and game scouts are now being given modern replacements for their ancient rifles, and the government should make a strong public condemnation of poaching, and urge the local magistrates to co-operate with the national park and game authorities. More efforts should be made not only to arrest poachers in the field, but also to track down and apprehend middlemen and dealers in rhino horn and ivory on a national and international level.

The rhinos in northern Tanzania have been seriously reduced, and everything must be done to give the remaining populations a chance of survival.

\section{Acknowledgments}

The Frankfurt Zoological Society financed all the aerial surveys and ground surveys in Ngorongoro and Burigi. I am grateful to the Director and the Wardens of Tanzania National Parks and to the Director of the Serengeti Wildlife Research Institute who provided information and were very helpful in planning and carrying out the surveys. S. Makacha, staff scientist of Ngorongoro, contributed a lot of data on Ngorongoro and Maswa. I am indebted to W.B. Sumay, M. Borner and J. Shelkey who acted as navigators/observers and to A.L. Metili, L. and D. Rechsteiner and B. Borner who were observers. P. ole Sayalel organised the ground count in the Crater and $\mathrm{Mr}$ Mongi accompanied me on my ground survey in Burigi. Finally, I would like to thank all scientists, rangers and game scouts who contributed to the success of the survey. 


\section{References}

1. BABU, D.S. 1980 Pers. comm.

2. BORNER, M. 1979. A Field Study of the Sumatran Rhinoceros (Dicerorhinus sumatrensis F.). Ph.D. thesis, University of Basel. 169pp.

3. BORNER, M. 1980. Ecological Survey, Rubondo Island National Park. Progress Reports to the Frankfurt Zoological Society.

4. BRADLEY MARTIN, E. 1979. The International Trade in Rhinoceros Products. Report to WWF/IUCN. 68pp. Summary, Oryx 15: 322-3.

5. ECOSYSTEMS LTD 1980. The Status and Utilisation of Wildlife in Arusha Region, Tanzania. Final Report, Ecosystems Ltd, Nairobi. 82pp.

6. FOSBROOKE, H. 1972. Ngorongoro: The Eighth Wonder. Deutsch, London.

7. FRAME, G.W. 1980. Black rhinoceros (Diceros bicornis L.) subpopulation on the Serengeti plains, Tanzania. Afr. F. Ecol. 18: paper 26.

8. GODDARD, J. 1976a. The validity of censusing black rhinoceros populations from the air. E. Afr. Wildl. F. 5: 18-23.

9. GODDARD, J. 1976b. Home range, behaviour and recruitment rates of two black rhinoceros populations. E. Afr. Wildl. J. 5: 133-50.

10. GODDARD, J. 1968. Food preferences of two black rhinoceros populations, $E$. Afr. Wildl. F. 6: 1-18.

11. GRIMSDELL, J.J.R. 1978. Estimated population sizes of the large mammals of the Serengeti. Report to CPW Serengeti, mimeo.

12. HILLMAN, K. 1979. Past and present estimates of rhino numbers in Tanzania. IUCN/SSC African Rhino Group, Nairobi.

13. HILLMAN, K. 1980. Newsletter No. 1. IUCN/SSC African Rhino Group, Nairobi.

14. KANZA, B. 1979. Pers. comm.

15. KLINGEL, H., and U. KLINGEL 1966. The rhinoceros of Ngorongoro crater. Oryx 8: 302-6.

16. LEAKEY, M.D. 1980. Pers. comm.

17. LOHAY, M. 1977. Records of poached rhino in Tanzania National parks from 1975 to $1977.2 \mathrm{pp}$. Also, pers. comm.

18. MAKACHA, S., C.L. MOLLEL and J. RWEZAURA 1979. The conservation status of the black rhinoceros (Diceros bicornis L.) in the Ngorongoro crater, Tanzania. Afr. F. Ecol. 17: 97-103.

19. MAKACHA, S., M.J. MSINGWA and G.W. FRAME 1980. Conservation problems in the Endulen Zone (Ngorongoro Conservation Area) and Maswa Game Reserve, Tanzania. Mimeo, 23pp.

20. MAKACHA, S. 1980 . Pers. comm.

21. METILI, L.L. 1980. Pers. comm.

22. MGINA, A. 1979. Pers. comm.

23. MOIRANA, L.M. 1980. Pers. comm.

24. MWALYOSI, R.B. 1978. Pers. comm.

25. NORTON-GRIFFITHS, M. 1972. Serengeti Ecological Monitoring Program. African Wildlife Leadership Foundation, Nairobi. 25pp.

26. NORTON-GRIFFITHS, M. 1978. Counting Animals. Handbook 1, second edition. African Wildlife Leadership Foundation, Nairobi. 139pp.

27. OLE SAYALEL, P. 1979. Pers. comm.

28. SCHENKEL, R., and L. SCHENKEL 1969. Ecology and Behaviour of the black rhinoceros. Mammalia Depicta, Parey. $101 \mathrm{pp}$.

29. TANAPA 1980. Summary of conservation offenses. Numbers of animals killed and weapons confiscated for the period of October 79 to February 80. Tanzania National Parks, Arusha. 